This PDF is a selection from an out-of-print volume from the National Bureau of Economic Research

Volume Title: Money in Historical Perspective

Volume Author/Editor: Anna J. Schwartz

Volume Publisher: University of Chicago Press

Volume ISBN: 0-226-74228-8

Volume URL: http://www.nber.org/books/schw87-1

Publication Date: 1987

Chapter Title: Has the Growth of Money Substitutes Hindered Monetary Policy?

Chapter Author: Phillip Cagan, Anna J. Schwartz

Chapter URL: http://www.nber.org/chapters/c7503

Chapter pages in book: (p. 209 - 233) 


\section{8 \\ Has the Growth of Money Substitutes Hindered Monetary Policy?}

Phillip Cagan and Anna J. Schwartz

\subsection{Introduction}

In the decade following World War II the efficacy of monetary policy as a tool for stabilizing the economy was widely debated. Many reasons were offered for questioning the efficacy of monetary policy, but most of them derived from the judgment that the interest elasticity of demand for money balances was or had become quite high. This was the main theme of Warren Smith's influential article "On the Effectiveness of Monetary Policy" 1 and of numerous other writings in the early post-World War II period before and after the Treasury-Federal Reserve Accord.

The emphasis on interest elasticity was inspired by the theoretical notion of a "liquidity trap," D. H. Robertson's (1940) apt phrase for the Keynesian special case of an infinitely elastic liquidity preference schedule, to which the monetary literature has obsessedly devoted so much attention..$^{2}$ A liquidity trap is clearly damaging to the efficacy of monetary policy, notwithstanding the Pigou wealth effect and the Patinkin real-balance effect. This is so because it implies that open-market purchases will lead money holders to absorb additional money balances and open-market sales will lead them to absorb bonds without any effect on aggregate spending on goods and services. To be sure, if the elasticity is anything less than infinite, open-market operations will affect such spending. The size of the operation required to produce the desired effect on spending in the short run is, nevertheless, positively related to the elasticity. If the elasticity is finite but very high, therefore, effective operations for stabilization purposes will have to be very large.

The authors are grateful for comments on an earlier draft from Karl Brunner, Franklin Edwards, Arthur Gandolfi, Benjamin Klein, James Lothian, Allan H. Meltzer, and William Silber. 
Why be concerned about large operations? The resource costs of open-market operations do not rise with increases in size (money today is created at near zero marginal cost). Large operations are said to be harmful and undesirable because they have disruptive side effects on financial institutions and markets. ${ }^{3}$ Ironically, these effects have shown up mainly in periods of severe monetary restraint (such as 1966 and 1969-70) precisely because of large changes in interest rates. For moderate changes of monetary policy in which financial effects are tolerable, large operations would be a problem only if the size of errors in the execution of policy due to faulty forecasting were positively related to the size of operations. If so (which is not at all obvious), high elasticity would mean that operations large enough to do the job exposed the economy to large errors of policy. It would then be better to rely on some other policy tool (if it exists) for which the effects of likely errors were smaller.

Seeming support for these views came from the growing complexity of financial markets and particularly from the growing importance of financial intermediaries. Goldsmith's empirical documentation of The Share of Financial Intermediaries in National Wealth and National Assets, 1900-49 was published in 1954 and heightened the recognition of this historical development. Financial intermediaries were providing a rapidly growing quantity of deposit liabilities and other liquid assets which are close substitutes for checking account money. The widely discussed writings of Gurley and Shaw $(1955,1956,1957)$ highlighted the diminished role of commercial banks in financial markets and raised doubts about the effectiveness of traditional monetary policy, since monetary authorities lacked control over a growing part of the financial system. Their conclusions were cautious, but many others extended their argument to claim that the growth of money substitutes had raised the interest elasticity of money demand and thus had reduced central bank control via open market operations. Later the Radcliffe Report in Great Britain (1959) viewed monetary policy as impotent, submerged in a sea of liquidity. The decline and fall of monetary policy was prematurely but widely proclaimed.

This earlier skepticism over the efficacy of monetary policy has diminished in the United States, and in recent years its powerful effects are generally acknowledged. Much controversy remains, however, particularly concerning its proper conduct and whether a flexible policy is desirable. But the objection to a flexible policy is based on lags in the effects and is different from the earlier criticism based on allegedly high cross-elasticities between money and other assets. Controversies over monetary policy are a tradition which goes back centuries; the corner of economics concerned with monetary theory would seem strangely peaceful without them. Our interest in this now-dated con- 
troversy reflects in part a desire to tidy up the history of monetary economics and, more importantly, a desire to help resolve some of the questions left open. The implications of the growth of financial intermediaries, despite the earlier misconceptions, are still important to monetary theory and policy.

The passage of time allows us to test the centerpiece of the earlier view: Has the growth of financial intermediaries and other financial instruments increased the short-run interest elasticity of demand for money balances (interpreted here as $M_{1}$ )? This question summarizes the concern of most of the discussion since the $1950 \mathrm{~s}$. While the interest elasticity of money demand is pertinent to the effect of the growth of financial intermediaries, preoccupation with that elasticity in this paper does not imply a denial of channels of monetary effects which bypass financial markets.

An earlier view expounded by Henry Simons (1936) was that the growth of money substitutes was contributing to financial instability, which could be interpreted to mean instability of the demand function for money expressed in terms of the usual variables. We do not take up the instability argument here because it is largely neglected in the postwar literature dealing with the efficacy of monetary policy.

Three earlier studies presented estimates suggesting that the interest elasticity had declined. In his examination of the elasticity over a long period, Meltzer (1963) provided decade estimates which showed a decline from the 1920 s to the $1950 \mathrm{~s}$. He was concerned with other issues, however, and did not comment on the decline. Teigen (1964), who took a two-equation approach to allow for supply effects, estimated the short-run interest elasticity of money demand to be -.09 from annual data for 1924-41 and -.02 from quarterly data for 1946.IV-1959.IV. $\mathrm{He}$ expressed surprise over the decline and attributed it to a reduction in the use of money as a store of wealth. Laidler (1966) reported a similar decline for first differences of annual data 1919-40 and 194660 but virtually no change in the elasticity for levels of the variables. Although we believe that the decline in interest elasticity that these three studies suggested was correct, their estimates of the difference between the 1920s and post-World War II must be regarded as tentative. Only short stretches of the later period were available at the time those studies were undertaken. Furthermore, except for Meltzer's, they included some data from 1942 to 1953 -years that were contaminated by the Federal Reserve bond-support program.

At the time of writing (1972) the period for estimating the interest elasticity since the end of that program covered nearly twenty subsequent years. For comparison with an earlier period of similar economic conditions, we selected 1921-31. We examined a variety of alternative regressions designed to make estimates for the earlier and the later 
period fully comparable. Most of our estimates also show a decline in the interest elasticity. In a final section we discuss some reasons for the decline and the implications for policy. We also point out, as have previous studies, that the short-run elasticity, while lower in the postwar period, has never been very high.

\subsection{Statistical Results}

To test for changes in the interest elasticity of money demand, we estimated demand functions of various forms for quarterly data 1921.I1931.IV and 1954.I-1971.IV. The first period begins on the earliest date for which quarterly GNP estimates are available. We wanted to make the earlier period as long as possible but believed that the abnormal fluctuations following Britain's suspension of gold payments should be excluded. The second period begins for obvious reasons with the actual (not official) termination of the Federal Reserve bond support program and ends with the latest data available at the time of computation. (Because of problems associated with the sharp rise in interest rates after 1965 discussed further below, we also use the truncated period 1954.I-1965.IV.) We omitted from consideration the intervening period $1932-53$ because of the series of shocks due to the banking crisis, severe depression, wartime controls, and bond support program. The earlier period and the later truncated period are reasonably comparable in general economic climate (except perhaps for the business contraction of 1921, which was more severe than any contraction since World War II), but differ substantially in the relative importance of financial intermediaries. For example, the ratio of $M_{1} / M_{3}$ in 1924 was .49 , and in 1964 was .37 .4

In estimating the interest elasticity of demand for money balances, we are immediately faced with a choice of interest rates. Ideally, we should include the yields on all relevant substitutes for money, but multicollinearity makes a broad inclusion impractical. We have confined the statistical analysis to the average rate paid on savings deposits and to short-term rates on open-market instruments, principally commercial paper but also Treasury bills and call money. We interpret the concern in the literature over the efficacy of monetary policy to pertain to a short-run interest elasticity and, accordingly, we focus on shortterm open-market rates. The particular series used were selected mainly because they are available for both periods; nevertheless, they are generally representative of short-term rates.

In examining the efficacy of monetary policy, it is important to separate the short-run from the long-run response of money demand to interest rates. Monetary policy also effects long-term rates; such effects are important, to be sure, but in the short run short-term open market 
rates generally display the strongest response to policy and the strongest effects on the demand for money balances.

In addition to interest rates, money demand equations contain real income or wealth. We use GNP, since it is the best of such aggregate series available quarterly for the earlier period. We use current GNP rather than, as is common, some moving average to approximate the concept of permanent income. This transformation will affect the absolute size of the interest coefficient but very likely not the comparative size between periods. We have omitted those variations in the specification of the regression equation which appear least likely to affect the comparison between periods.

\subsubsection{A Standard Money Demand Equation}

A standard form is

$$
\text { 1n } M / P=k+a \text { ln } G N P / P+b i
$$

where 1 denotes natural logarithm, $M / P$ is deflated money balances, $G N P / P$ real gross national product, $i$ a short-term interest rate, and $k$ the constant intercept. $k$ and $a$ and $b$ are regression coefficients to be estimated. To deflate $M$ and $G N P$, we use the consumer price index for the earlier period and the GNP deflator (not available for the 1920s) for the later period. We shall refer to $b$, which theoretically should be negative in this form of the function, as the interest coefficient or slope of demand (not elasticity), because it is the percentage change in demand with respect to arithmetic (not percentage) changes in the interest rate (measured as percent per annum). ${ }^{5}$ We purposely do not use the logarithm of the interest rate in the equation in order to avoid the resulting blow-up of small changes which occurs at low levels of the interest rate. Unlike $M$ and $G N P$, the interest rate is not a dollar magnitude but a percentage rate, and therefore it does not require a $\log$ transformation to avoid heteroscedasticity. ${ }^{6}$ Since the interest slope and elasticity move in the same direction, no important theoretical or policy issue is raised by our choice of form.

Regressions of the form of equation (1) are shown in table 8.1. The most appropriate interest rate available for both periods is the commercial paper rate. As a second choice, we compare the call money rate in the earlier period with the three-month Treasury bill rate in the later period; call loans played a role in the 1920s paralleling that of Treasury bills in the post-World War II money market.

We note that the interest coefficient has a larger negative value (statistically significant) in the earlier period, but we were not disposed to accept these results without further examination of some problems. For one thing, the interest coefficient for the later full period is positive (it should be negative to indicate a substitution between money and 
Table 8.1

Standard Money Demand Equation $(\ln M / P=k+a \ln G N P / P+$ $\left.b i^{c}\right)$

\begin{tabular}{|c|c|c|c|c|c|}
\hline \multirow[b]{2}{*}{ Period } & \multicolumn{5}{|c|}{ Regression Coefficients (and $t$ values) } \\
\hline & $\begin{array}{l}\ln G N P / P \\
a\end{array}$ & $\begin{array}{l}\text { Commercial } \\
\text { Paper Rate } \\
b\end{array}$ & $\begin{array}{l}\text { Call Money } \\
\text { Rate } \\
b\end{array}$ & $\begin{array}{l}\text { Treasury } \\
\text { Bill Rate } \\
b\end{array}$ & $\begin{array}{l}\text { Adj. } \\
R^{2}\end{array}$ \\
\hline 1921.I-1931.IV & $\begin{array}{r}.49 \\
(15.8)\end{array}$ & $\begin{array}{c}-2.7 \\
(7.2)\end{array}$ & - & - & .89 \\
\hline & $\begin{array}{r}.57 \\
(15.4)\end{array}$ & - & $\begin{array}{c}-1.5 \\
(4.8)\end{array}$ & - & .85 \\
\hline 1954.I-1965.IV & $\begin{array}{r}.08 \\
(1.8)\end{array}$ & $\begin{array}{c}-1.3 \\
(2.0)\end{array}$ & - & - & .05 \\
\hline & $\begin{array}{r}.04 \\
(0.9)\end{array}$ & - & - & $\begin{array}{c}-0.5 \\
(0.8)\end{array}$ & .00 \\
\hline 1954.I-1971.IV & $\begin{array}{r}.17 \\
(5.0)\end{array}$ & $\begin{array}{r}+0.2 \\
(0.4)\end{array}$ & - & - & .59 \\
\hline & $\begin{array}{r}.16 \\
(4.4)\end{array}$ & - & - & $\begin{array}{c}+0.3 \\
(0.6)\end{array}$ & .59 \\
\hline
\end{tabular}

Source: See Appendix.

Note: Signs of $t$ values have been dropped. Units of measurement: $a$ is an elasticity, $b$ is the percentage change in dependent variable per arithmetic change of 1 percentage point in the interest rate. ${ }^{c}$ denotes a short-term interest rate, measured as a decimal like .04. Estimate of the regression constant $k$ is not shown.

other assets). When the years after 1965 are omitted, the coefficient reverses sign. The positive coefficients are not statistically significant and may be interpreted as essentially zero.

The later years present a problem. After 1966 the trend of the money stock relative to that of GNP rose, as is shown in figures 8.1 and 8.2 by the slower upward trend in the velocity ratio (GNP to the money stock) for those years. The regression associates this change in relative trends with the sharp rise in the interest rate, which tends to pull the regression coefficient for the interest rate in a positive direction and thus hides all or part of the negative substitution effect. The positive association is misleading: The change in relative trends of money and GNP after 1966 is not to be explained by the outbreak of inflation and the accompanying increase in the anticipated rate of inflation and in interest rates. The increase would, if anything, reduce the demand for money balances and raise the upward trend of velocity. It may be that the inflation increased uncertainty and for that reason increased money demand, ${ }^{7}$ but no proxy for uncertainty has found wide use, and we have not experimented with one.

There is the additional problem that, to some extent, the positive coefficient may be indicative of an extraneous supply effect in which 


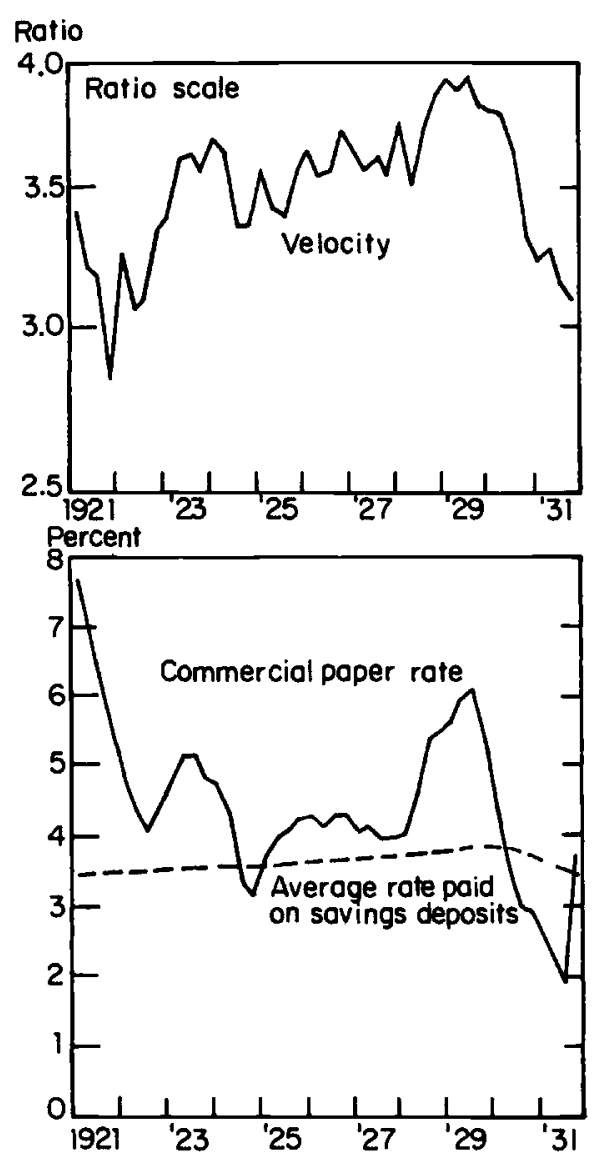

Fig. 8.1

Velocity, commercial paper rate, and average rate paid on savings deposits, quarterly, 1921-31.

rising interest rates induced an expansion of the money stock. This supply effect may have been stronger than usual during these years owing to the sharp restraints imposed by policy. We have not tried to allow econometrically for supply effects for two reasons. One is the difficulty of doing so satisfactorily. The second is that we interpret other evidence to indicate that the interest elasticity of supply is usually small and equally unimportant in both periods, except perhaps for the years after $1965 .^{8}$ This is so both with respect to the feedback on the deposit multiplier and consistency of the response of the monetary base to market rates.

For purposes of this temporal comparison we focus on the truncated period 1954-65. We give results for the full period, nevertheless, which 

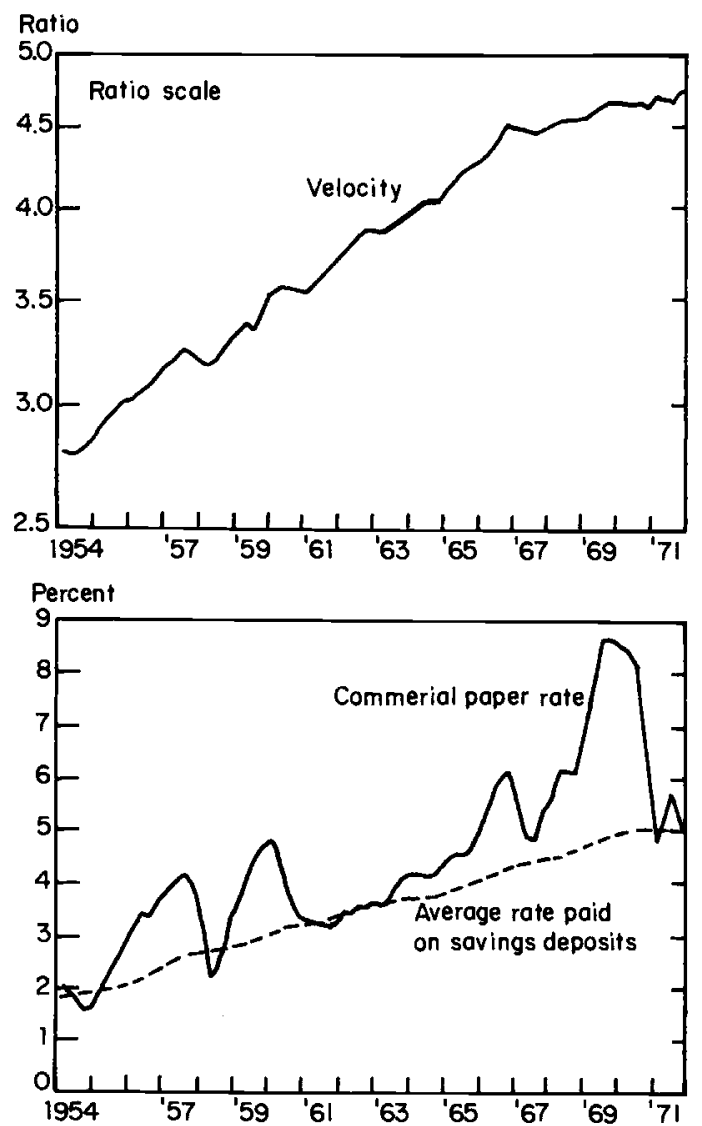

Fig. 8.2

Velocity, commercial paper rate, and average rate paid on savings deposits, quarterly, 1954-71.

do not alter our main conclusions. The unexplained change in trend is one piece of evidence of instability of the demand function, admittedly, but it does not shift the weight of the evidence on the comparison of elasticities.

A different problem of trend exists for the truncated period, because the variables all have had steeply rising trends since World War II. Upward trends in velocity since World II appear to be worldwide occurrence, which presumably reflects in large part the accompanying rise in interest rates and inflation. But any other variable with a rising trend which has influenced money demand and is omitted from the regression will be collinear with the trends in GNP and the interest rate and be partly represented by them. If the interest rate happens to correlate with the omitted influence, the estimate of the interest coef- 
ficient will be affected. Omitted influences which may have been important are the upward trend in the rate of interest on savings deposits, improvements in their quality (in the United States due in part to favorable terms enacted in $\mathbf{1 9 5 0}$ for federal deposit insurance on savings and loan deposits), and improvements in cash management techniques and technology. Although the last two developments may have come at particular points in time, the response of money demand to them could have occurred slowly over many years and so have made their effects appear as a trend influence.

The following tables report our various attempts to allow for the trend by including other variables or short-run adjustment terms, in order to ascertain the effect, if any, on the estimates of the short-run interest elasticity. Our conclusions are presented at the end of this section.

\subsubsection{Money Demand Equations with a Variable to Account for Trend}

An appealing candidate for such a variable is the average rate paid on savings deposits. This is relevant to the growth of savings deposits as substitutes for demand deposits. It may be explained in part by a general rise since World War II in the interest rate paid on savings relative to a zero rate, because of the prohibition since 1933 on demand deposits. (We ignore checking charges as insignificant. The possibility that increases in services or indirect payments on demand deposits took the place of prohibited interest payments is considered later.) The effect of the rise in the interest rate on savings deposits probably occurred gradually over many years; the short-run changes in this rate were small (even though the rates paid on large denomination certificates of deposit beginning in the mid-1960s behave like commercial paper rates), and the short-run response to its changes was likely low. If we allow for the gradual effect of the savings deposit rate on money demand, the commercial paper rate is relieved from acting as proxy for the upward trend in the savings deposit rate, and the coefficient of the paper rate should then reveal the short-run response of money demand to changes in open market rates. There is sufficient dissimilarity between the movements in these two rates for the regression to distinguish their effects on money demand (see figures 8.1 and 8.2).

Table 8.2 presents these regressions. The savings deposit rate, $i^{s}$, is an annual series interpolated for quarterly values. It is an average of the rates paid on U.S. postal savings and time and savings deposits of commercial banks, mutual savings banks, and savings and loan associations (the last was omitted as relatively unimportant for the earlier period), each weighted by the relative amounts outstanding. (The call money and Treasury bill rates are not used here and subsequently, 
Table 8.2

Money Demand Equation with Two Interest Rates $\ln M / P=k+$ $a \ln G N P / P+f^{s}+b i^{c}$

\begin{tabular}{|c|c|c|c|c|}
\hline \multirow[b]{2}{*}{ Period } & \multicolumn{4}{|c|}{ Regression Coefficients (and $t$ values) } \\
\hline & $\begin{array}{l}\ln G N P / P \\
a\end{array}$ & $\begin{array}{l}\text { Savings } \\
\text { Deposit Rate } \\
f\end{array}$ & $\begin{array}{l}\text { Commercial } \\
\text { Paper Rate } \\
b\end{array}$ & $\begin{array}{l}\text { Adj. } \\
R^{2}\end{array}$ \\
\hline 1921.I-1931.IV & $\begin{array}{r}.45 \\
(6.8)\end{array}$ & $\begin{array}{c}+6.4 \\
(0.8)\end{array}$ & $\begin{array}{c}-2.8 \\
(7.1)\end{array}$ & .89 \\
\hline & $\begin{array}{r}.49 \\
(15.8)\end{array}$ & - & $\begin{array}{c}-2.7 \\
(7.2)\end{array}$ & .89 \\
\hline 1954.I-1965.IV & $\begin{array}{r}.69 \\
(23.7)\end{array}$ & $\begin{array}{c}-11.8 \\
(23.2)\end{array}$ & $\begin{array}{c}-0.7 \\
(4.2)\end{array}$ & .93 \\
\hline 1954.I- 1971.IV & $\begin{array}{r}.73 \\
(11.4)\end{array}$ & $\begin{array}{r}-11.5 \\
(9.3)\end{array}$ & $\begin{array}{c}+0.4 \\
(1.4)\end{array}$ & .82 \\
\hline
\end{tabular}

Source: See Appendix.

Note: Signs of $t$ values have been dropped. Units of measurement: same as for table 8.1. $i^{s}$ denotes the savings deposit rate and $i^{c}$ a short-term interest rate. Second line is taken from table 8.1. Estimate of the regression constant $k$ is not shown.

inasmuch as they gave essentially the same results in table 8.1 as the commercial paper rate did.)

While the savings deposit rate has the correct negative sign for the later period and helps to raise the implausibly low GNP elasticity as compared with table 8.1, the inclusion of this rate has no effect on the coefficient of the commercial paper rate (except to raise its statistical significance), which still appears to be lower (in absolute value) for the later periods and incorrectly positive for the later full period. The savings deposit rate has an incorrect positive sign for the earlier period, but the coefficient is not statistically significant and probably should be disregarded. The results with it omitted in that period are also shown. This rate displayed very little variation in the earlier period (the maximum range was from 3.5 to 3.8 percent per annum) and so had too little effect on money demand to be measured adequately, unlike its substantial long-run rise in the later period.

\subsubsection{Velocity Equations with Trend Influences}

For most of this century taken as a whole, $M_{1}$ velocity has no clearcut trend, and estimates of the elasticity of $M_{1}$ with respect to wealth or permanent income for periods before World War II with a span of two decades or longer are around unity. (See Meltzer 1963.) Yet in tables 8.1 and 8.2 the elasticity for real GNP is well below unity. What is the reason? We have thought of three possibilities, the last of which may affect our estimates of the interest coefficient. First, the income 
elasticity of transactions velocity may in fact be below unity, as Irving Fisher believed, but the income elasticity used to be dominated by a higher income elasticity of balances held as a store of wealth. These may no longer dominate because of the availability since World War II of many good substitutes. Second, our use of current GNP incorporates transitory changes, which by the permanent-income theory have smaller effects on money demand than the permanent component (but see Darby 1972) and therefore pull the estimated elasticity below the long-run level of unity. Since transitory changes are a larger fraction of total variance in shorter periods, this may explain the low elasticities for the 1920s as well as post-World War II. Finally, third, there could be a statistical misattribution of trends. If the negative effect of the interest rate is suppressed for some reason and its regression coefficient becomes zero or positive, the rising trend of GNP relative to the money stock in the post-World War II period can be "explained" in the regression by reducing the coefficient for GNP. This may account for the very low estimates of the real GNP elasticity for the later period in table 8.1.

To test whether trend movements were improperly lowering the GNP elasticity and thereby introducing difficulties for the interest coefficients, we forced the GNP elasticity to be unity. The results, presented in table 8.3 increase the effect of the savings deposit rate and lower that of the commercial paper rate, which nonetheless was still larger for the earlier period. 9

With monetary velocity as the dependent variable, the theoretically correct signs of the interest-rate coefficients are positive. The problem

\begin{tabular}{lccc}
\hline & \multicolumn{3}{c}{ Regression Coefficients (and $t$ values) } \\
\cline { 2 - 4 } & Savings & Commercial & \\
& Deposit Rate & Paper Rate & Adj. \\
Period & $f$ & $b$ & $R^{2}$ \\
\hline 1921.I-1931.IV & 50.0 & +1.6 & .63 \\
& $(8.3)$ & $(2.6)$ & .99 \\
1954.I-1965.IV & 16.7 & +1.2 & .98 \\
& $(43.8)$ & $(3.9)$ & .98 \\
1954.I-1971.IV & 16.4 & -0.1 & \\
& $(33.0)$ & $(0.3)$ &
\end{tabular}

Source: See Appendix.

Note: Signs of $t$ values have been dropped. Units of measurement: for $V$, percentage change in velocity per year; for other coefficients, same as for table 8.1. V is GNP/M, $i^{s}$ is savings deposit rate, and $i^{c}$ is a short-term interest rate. Estimate of the regression constant $k$ is not shown. 
with the years after 1965, noted above, is exemplified here by a negative coefficient for the commercial paper rate. The reason for the wrong sign is not hard to find: The slower upward trend of velocity after 1966 is not explained by the savings deposit rate. It continues to rise despite the largely unchanged regulatory ceilings on these rates, ${ }^{10}$ because the rates paid by many institutions were still below the ceilings and could go higher. Consequently, the regression "calls upon" the commercial paper rate, which rose sharply after 1965 as did all other open market rates, to explain this decline in trend of velocity, thus turning the coefficient of the paper rate negative-quite inappropriately. Since the outbreak of the Vietnam inflation and associated increases in interest rate would explain a rise in monetary velocity, the decline in trend remains a puzzle. ${ }^{11}$ It is not readily explained by any of the other variables commonly included in the money demand function such as permanent rather than current income-which is used to distinguish between anticipated and transitory changes in income. No sharp difference in trends occurred between current and permanent income, however measured, after 1966.

Confining our attention to the top two regressions in the table, we find that the coefficient of the paper rate was lower in the later period than in the 1920s. This is also true of the savings deposit rate by a large margin. A deposit-rate coefficient of 17 for the later period does not seem too high as a reflection of the substitution between savings and demand deposits. (It means that the demand for money balances declines 17 percent for each rise in the rate of 1 percentage point.) The coefficient of 50 for the 1920 s does seem too high, however, since these assets (except for postal savings) were not federally insured and for this reason, among others, were not as good substitutes for demand deposits then as they became in the $1950 \mathrm{~s} .{ }^{12}$ As already noted, the savings deposit rate changed very little during the earlier period, and such a high coefficient suggests that it is spuriously representing other influences. If we exclude it for the earlier period, the simple regression of $1 \mathrm{n} G N P / M$ on the paper rate gives a smaller coefficient of 1.4 (n. 9), which is still larger than those for the later period in table 8.2. If we force the deposit-rate coefficient to be the same in both periods by means of a pooled regression, we obtain a higher coefficient for the commercial paper rate in the earlier period, though not significantly higher. ${ }^{13}$

In the absence of a common proxy for trend influences on velocity in both periods, we may as an alternative employ a simple time trend like $T$ in table 8.4. The results show once again that the simple correlation between velocity and the commercial paper rate in the later period (n. 9) reflects the trend in these series. The response of money demand to interest-rate deviations from the later trend gives a coeffi- 
Table 8.4

Velocity Equation with Time Trend $\ln V=k+g T+b i^{c}$

\begin{tabular}{lccc}
\hline & \multicolumn{3}{c}{ Regression Coefficients (and $t$ values) } \\
\cline { 2 - 4 } & Linear & Commercial & \\
Time Trend & Paper Rate & Adj. \\
Period & $g$ & $b$ & $R^{2}$ \\
\hline 1921.I-1931.IV & 1.43 & +3.3 & .30 \\
& $(4.2)$ & $(3.5)$ & .99 \\
1954.I-1965.IV & 3.31 & +1.2 & .98 \\
1954.I-1971.IV & $(55.9)$ & $(5.0)$ & .98 \\
& 3.07 & +0.3 & $(0.9)$ \\
\hline
\end{tabular}

Source: See Appendix.

Note: Signs of $t$ values have been dropped. Units of measurement: same as for tables 8.1 and 8.3. $T$ is a linear time trend, increasing one integer per year. Estimate of the regression constant $k$ is not shown.

cient in table 8.4 of a little above unity ( 0.3 including $1966-71)$, only about one-third the size of the coefficient for the 1920s.

The strong upward trend in velocity since World War II can be interpreted as representing a long-run response to increases in the total return to money substitutes (including nonpecuniary returns from management technology and quality). Until a measure of this return is provided, we cannot estimate the corresponding demand elasticity. But, for present purposes, that is not crucial. The time trend is satisfactory as long as it correctly tracks long-run influences. Admittedly, a linear time trend may spuriously absorb some of the correlation between velocity and the paper rate, thus reducing the estimate of the shortrun interest-rate effect. Although future developments will provide a test of this possibility (since these influences should gradually slacken), at present it remains unconfirmed.

As an alternative approach we may turn to adjustment equations, which are also designed to abstract from long-run influences.

\subsubsection{Demand Equations with Short-Run Adjustments}

A standard adjustment equation postulates that

$$
\Delta \ln V=e\left(\ln V^{d}-\ln V\right),
$$

in which the change in velocity is proportional to the percentage difference between desired $\left(V^{d}\right)$ and actual velocity. In discrete form,

$$
\ln V_{t}=e \ln V_{t}^{d}+(1-e) \ln V_{t-1}
$$

where

$$
\ln V_{t}^{d}=f i_{t}^{s}+b i_{t}^{c}+k
$$


and

$$
0<e \leq 1 \text {. }
$$

Substituting (4) into (3) we derive

$$
\ln V_{t}=e k+e f i_{\mathrm{s}}^{s}+e b i_{t}^{c}+(1-e) \ln V_{t-1}
$$

where $e f$ and $e b$ are the short-run (within one quarter) responses to changes in interest rates. Regressions of this form are presented in table 8.5.

These regressions also show the short-run interest effect to be larger in the earlier period. The estimate for the later period is held down, however, by the unusually high coefficient on the lagged dependent variable, as a result of the strong upward trend in velocity. (As noted before, this is responsible for the very high implied estimates of the long-run effects, here $f$ and $b$.) To circumvent this trend bias, the third line shows the results of a regression in which the adjustment coefficient $1-e$ is assigned the (lower) value estimated for the 1920s. As a result, the estimates of the short-run interest effect are raised, though they still lie below those for the earlier period.

The equations in Table 8.5 presuppose that money balances are adjusted to their desired level relative to GNP-which is to say that monetary velocity is the variable being adjusted. An alternative and

Velocity Equation with Adjustment Term $\ln V_{t}=e k+e f i_{t}^{s}+e b i_{i}^{c}$

\begin{tabular}{|c|c|c|c|c|}
\hline \multirow[b]{2}{*}{ Period } & \multicolumn{4}{|c|}{ Regression Coefficients (and $t$ values) } \\
\hline & $\begin{array}{l}\text { Savings } \\
\text { Deposit Rate } \\
e f\end{array}$ & $\begin{array}{l}\text { Commercial } \\
\text { Paper Rate } \\
e b\end{array}$ & $\begin{array}{l}\text { Lagged } \\
\text { Velocity } \\
1-e\end{array}$ & $\begin{array}{l}\text { Adj. } \\
R^{2}\end{array}$ \\
\hline 1921.I-1931.IV & $\begin{array}{l}28.8 \\
(2.9)\end{array}$ & $\begin{array}{r}+1.2 \\
(2.0)\end{array}$ & $\begin{array}{r}0.41 \\
(2.6)\end{array}$ & .68 \\
\hline 1954.I-1965.IV & $\begin{array}{c}3.6 \\
(2.0)\end{array}$ & $\begin{array}{c}+0.5 \\
(2.1)\end{array}$ & $\begin{array}{c}0.77 \\
(7.4)\end{array}$ & .99 \\
\hline $1-e \operatorname{set}^{*}=.41$ & $\begin{array}{r}9.7 \\
(33.8)\end{array}$ & $\begin{array}{c}+0.8 \\
(3.5)\end{array}$ & - & .98 \\
\hline 1954.I-1971.IV & $\begin{array}{c}-0.1 \\
(0.1)\end{array}$ & $\begin{array}{r}+0.05 \\
(0.4)\end{array}$ & $\begin{array}{r}0.99 \\
(19.3)\end{array}$ & .997 \\
\hline
\end{tabular}
$+(1-e) \ln V_{t-1}$

Source: See Appendix.

Note: Signs of $t$ values have been dropped. For units of measurement and other notes: see tables 8.1 and 8.3. $e$ is percentage adjustment in dependent variable per quarter. Estimate of regression constant $k$ is not shown.

*Regression equation is $\left(\ln V_{t}-.41 \ln V_{t-1}\right)=e k+e f f_{t}^{s}+e b i c$. 
more common adjustment equation is based on money balances alone, where GNP helps determine the desired balances.

$$
\begin{gathered}
\Delta \ln M_{t}=e\left(\ln M_{t}^{d}-\ln M_{t-1}\right) \\
\ln M_{t}^{d}=k+a \ln G N P_{t}+f t_{t}^{s}+b i_{t}^{c} .
\end{gathered}
$$

Substituting (7) into (6) gives

(8) $\ln M_{t}=e k+e a \ln G N P_{t}+e f i_{t}^{s}+e b i_{t}^{c}+(1-e) \ln M_{t-1}$.

Regressions of this form are presented in table 8.6. (The savings deposit rate is not statistically significant in these equations and has little effect on the other coefficients; hence it has been omitted.) The coefficient of the commercial paper rate is very small but still double that in the later period after we assign the earlier value to the adjustment factor for the later period; otherwise it takes on a meaningless value above unity.

In adjustment equations the dependent variable is conventionally measured in undeflated dollars (since to measure in real terms implies an immediate adjustment of prices), and we have followed that convention in table 8.6. However, in doing so we implicitly assume that the elasticities of demand with respect to real GNP and to the price level are the same, since these two influences are combined in the GNP variable. (In equation (1), without the adjustment term, however, the elasticity with respect to the price level was unity and that of real GNP

Table 8.6

Money Demand Equation with Adjustment Term $\ln M_{i}=e k+$

\begin{tabular}{|c|c|c|c|c|}
\hline \multirow[b]{2}{*}{ Period } & \multicolumn{4}{|c|}{ Regression Coefficients (and $t$ values) } \\
\hline & $\begin{array}{l}\text { In } G N P \\
e a\end{array}$ & $\begin{array}{l}\text { Commercial } \\
\text { Paper Rate } \\
e b\end{array}$ & $\begin{array}{l}\text { Lagged } \\
\ln M \\
1-e\end{array}$ & $\begin{array}{l}\text { Adj. } \\
R^{2}\end{array}$ \\
\hline 1921.I-1931.IV & $\begin{array}{r}.21 \\
(5.2)\end{array}$ & $\begin{array}{c}-0.8 \\
(3.5)\end{array}$ & $\begin{array}{r}.61 \\
(8.1)\end{array}$ & .96 \\
\hline 1954.I-1965.IV & $\begin{array}{l}-.02 \\
(0.9)\end{array}$ & $\begin{array}{c}-0.6 \\
(6.4)\end{array}$ & $\begin{array}{r}1.14 \\
(21.3)\end{array}$ & .996 \\
\hline $1-e$ set $^{*}=.61$ & $\begin{array}{r}.15 \\
(19.4)\end{array}$ & $\begin{array}{c}-0.4 \\
(2.6)\end{array}$ & - & .93 \\
\hline 1954.I-1971.IV & $\begin{array}{r}.02 \\
(2.1)\end{array}$ & $\begin{array}{c}-0.3 \\
(4.2)\end{array}$ & $\begin{array}{r}1.01 \\
(52.4)\end{array}$ & .999 \\
\hline
\end{tabular}
$e a \ln G N P_{1}+e b i_{i}^{c}+(1-e) \ln M_{i-1}$

Source: See Appendix.

Note: Signs of $t$ values have been dropped. Units of measurement and other notes: see table 8.1. $e$ is percentage adjustment in dependent variable per quarter. Estimate of regression constant $k$ is not shown.

${ }^{*}$ Regression equation is $\left(\ln M_{t}-.61 \ln M_{t-1}\right)=e k+e a \ln G N P_{t}+e b i_{t}$. 
was allowed to be less than unity.) We can avoid this assumption by separating GNP into its real component and its price component, each with its own coefficient. This is usually not done because of difficulties in measuring the elasticity of the price deflator for short periods. Alternatively, we can avoid the assumption by treating real balances as the adjusting variable. (See Goldfeld 1973.) This has the drawback of implying either that the price level adjusts immediately to discrepancies between actual and desired balances while real GNP adjusts with a lag, or that the price level is to be taken as given and not affected by the discrepancy. Either assumption seems to us theoretically untenable, though as a practical empirical question it does not appear to matter much (as Goldfeld shows), since the price level deviates very little quarter to quarter from its trend.

Table 8.7 presents regressions with real balances as the adjusting variable. These regressions are more acceptable than those of table 8.6 for the later period, in that the adjustment coefficient $1-e$ is less than unity. It is nevertheless implausibly high, though somewhat lower when the interest rates are measured in logarithmic form (bottom panel); ${ }^{14}$ and the savings deposit rate for the earlier period is inappropriately positive though statistically insignificant. In any event, these regressions still show the coefficient for the commercial paper rate to be larger (in absolute value) for the earlier period.

A third way to avoid the assumption that the elasticity of the price deflator is the same as that of real GNP, and hence that the former

Table 8.7

Real Money Demand Equation with Adjustment Term

$\ln (M / P)_{t}=e k+e a \ln (G N P / P)_{t}+e f_{t}^{s}+e b i_{t}^{c}+(1-e) \ln (M / P)_{t-1}$

\begin{tabular}{|c|c|c|c|c|c|}
\hline \multirow[b]{2}{*}{ Period } & \multicolumn{5}{|c|}{ Regression Coefficients (and $t$ values) } \\
\hline & $\begin{array}{l}\ln G N P / P \\
e a\end{array}$ & $\begin{array}{l}\text { Deposit Rate } \\
\text { ef }\end{array}$ & $\begin{array}{l}\text { Commercial } \\
\text { Paper Rate } \\
e b\end{array}$ & $\begin{array}{l}\ln M / P \\
1-e\end{array}$ & $\begin{array}{l}\text { Adj } \\
R^{2}\end{array}$ \\
\hline 1921.I-1931.IV & $\begin{array}{r}.06 \\
(1.5)\end{array}$ & $\begin{array}{r}+4.04 \\
(1.2)\end{array}$ & $\begin{array}{l}-.90 \\
(3.9)\end{array}$ & $\begin{array}{r}.76 \\
(13.0)\end{array}$ & .98 \\
\hline \multirow[t]{2}{*}{ 1954.I-1971.IV } & $\begin{array}{r}.05 \\
(1.8)\end{array}$ & $\begin{array}{l}-.05 \\
(0.1)\end{array}$ & $\begin{array}{c}-.47 \\
(6.0\end{array}$ & $\begin{array}{r}.98 \\
(29.7)\end{array}$ & .99 \\
\hline & \multicolumn{5}{|c|}{ Same Equation But with Logarithm of Interest Rate } \\
\hline 1921.I-1931.IV & $\begin{array}{r}.07 \\
(1.7)\end{array}$ & $\begin{array}{l}+.16 \\
(1.3)\end{array}$ & $\begin{array}{l}-.04 \\
(4.1)\end{array}$ & $\begin{array}{r}.74 \\
(12.0)\end{array}$ & .98 \\
\hline 1954.I-1971.IV & $\begin{array}{r}.10 \\
(2.8)\end{array}$ & $\begin{array}{l}-.02 \\
(1.1)\end{array}$ & $\begin{array}{l}-.02 \\
(6.4)\end{array}$ & $\begin{array}{r}.89 \\
(16.5)\end{array}$ & .99 \\
\hline
\end{tabular}

Source: See Appendix.

Note: Signs of $t$ values have been dropped. Units of measurement and other notes: see table 8.1. $e$ is percentage adjustment in dependent variable per quarter. Estimate of regression constant $k$ is not shown. 
can be less than unity (implying "money illusion"), is to set both equal to unity, that is, in (8) set $a=1$. Then

$$
\begin{aligned}
\ln M_{t}-\ln G N P_{t}=k-\ln G N P_{t} & +e \ln G N P_{t} \\
& +e f i_{t}^{s}+e b i_{t}^{c}+(1-e) \ln M_{t-1}
\end{aligned}
$$

or

(10) $\ln (M / G N P)_{t}=e k+e f i_{t}^{s}+e b i_{t}^{c}+(1-e) \ln \left(M_{t-1} / G N P_{t}\right)$.

This is the general form used in a recent version of the (then named) FRB-MIT-Penn econometric model (1971). ${ }^{15}$

These regressions, presented in table 8.8 are one of the only two forms in which we found a larger coefficient for the commercial paper rate in the later truncated period than in the earlier period (the other was reported in n. 9). Both coefficients, however, are extremely small, as is the difference in size which makes them practically the same. Furthermore, these regressions are also not acceptable because of the unrealistically low adjustment speed (4 to 9 percent per quarter). This may result in part from upward bias in the adjustment term $1-e$ created by using concurrent $G N P$ in the dependent and the lagged variable. ${ }^{16}$

\subsubsection{Summary of Statistical Results}

Despite the difficulties of fitting a satisfactory money demand equation to the post-World War II period because of unresolved questions regarding the explanation for the relative trends in the variables, we believe that we have gone far enough to establish that the coefficient

Table 8.8

$$
\begin{aligned}
& \text { Money Demand Equation with Adjustment Term and Unitary } \\
& \text { Income Elasticity } \\
& \ln (M / G N P)_{t}=e k+e b i_{t}^{c}+(1-e) \ln \left(M_{t-1} / G N P_{t}\right)
\end{aligned}
$$

Regression Coefficients (and $t$ values)

\begin{tabular}{lccc}
\cline { 2 - 4 } Period & $\begin{array}{l}\text { Commercial } \\
\text { Paper Rate } \\
e b\end{array}$ & $\begin{array}{l}\ln \left(M_{t-1} / G N P_{t}\right) \\
1-e\end{array}$ & $\begin{array}{l}\text { Adj. } \\
R^{2}\end{array}$ \\
\hline 1921.I-1931.IV & -0.4 & .91 & .94 \\
& $(1.6)$ & $(25.8)$ & .99 \\
1954.I-1965.IV & -0.5 & .96 & .99 \\
& $(5.1)$ & $(130.8)$ & .999 \\
1954.I-1971.IV & -0.2 & .96 &
\end{tabular}

Source: See Appendix.

Note: Signs of $t$ values have been dropped. Units of measurement and other notes: See tables 8.1 and 8.3. $e$ is percentage adjustment in $M$ per quarter. Estimate of regression constant $k$ is not shown. 
(in absolute value) of a short-term interest rate is not higher in this period than in the 1920s and by most estimates is lower. This result does not appear to depend upon the interest-rate series used. The only regression in which the later period gave a significantly larger coefficient was for velocity on the commercial paper rate alone, with no other variable to account for the post-war upward trend in velocity. But that result clearly reflected a collinearity of trends, not the short-run variations which are relevant to the efficacy of monetary policy. The coefficient of the short-term interest rate was about the same or smaller for the later period in all the other equations which we fit to allow for trend influences on velocity: by including the savings deposit rate or a time trend, or by allowing for short-run adjustments. We interpret the results to mean that the short-run interest sensitivity of money demand has declined at least moderately since the 1920s.

Although many of the estimates of the long-run response to interest rates are sizable, the short-run response appears to be quite small in the earlier as well as the later period. Most of the short-run coefficients are less than 5 and many are around $1 / 2$ (in absolute value). When multiplied by .04 to convert to an elasticity, this gives a range of .2 to .02 . These estimates are on the low side but still within the range presented in most earlier studies. ${ }^{17}$ These numbers imply, for example, that an increase in the annual rate of growth of the money stock by a sizable 6 percentage points for one month (that is, an increase in $M_{1}$ of $1 / 2$ percent in one month) would depress short-term interest rates by $1 / 2$ divided by coefficients ranging from 5 to $1 / 2$. The change in short-term rates would be 0.1 to 1 percentage points, not an implausible range.

All of our equations treat the rate of return on money as constant. Charges on checking accounts we have intentionally ignored as of little importance, but deductions against fixed charges and services provided by commercial banks on these accounts could be important. Banks are able to increase the marginal return on demand deposits by raising the deduction against fixed charges on these accounts. The deduction varies with the minimum or average balance and so provides an implicit marginal rate of return. This rate has certainly risen over the postwar period, so that the net rate of return on money substitutes has risen less rapidly than gross interest rates. ${ }^{18}$ In addition, due to the prohibition of interest payments on demand deposits in 1933, commercial banks under competition have an incentive to provide services in lieu of interest. They also have an incentive to pay interest implicitly through lower net interest charges on loans to business depositors.

Since market interest rates probably overstate the changes in the net return on open-market instruments relative to that on money, our regressions bias the interest coefficient downward, and perhaps more 
so in the later period when services and implicit interest payments were likely to be more important. We know of no satisfactory method of allowing for this bias. ${ }^{19}$ Nevertheless, we strongly doubt its short-run importance. Account charges and services change very little in response to short-run changes in open market operations, which we are mainly concerned with here.

\subsection{Implications for Monetary Policy}

How could a decline in the interest sensitivity of money demand have occurred alongside the growth of money substitutes? There is an obvious reason. As Alvin Marty (1961) suggested might happen in his review of the Gurley-Shaw thesis, the growth of substitutes has shifted the money demand function to the left and in good part extinguished the holdings which were once close substitutes for savings deposits. These were balances which satisfied a "wealth" or "asset" demand for money. The remaining holdings have come to be largely "transactions" balances, and their demand is, presumably, less sensitive to changes in interest rates. ${ }^{20}$ Our results give empirical substance to these theoretical conjectures.

Given that the response of money demand to changes in interest rates has declined, inversion of the relationship implies that a given amount of change in the money stock now produces a larger short-run effect on interest rates. ${ }^{21}$ This increases monetary effects on interest rates and, for a given size of policy action, increases the short-run effect on that part of aggregate spending which is influenced by interest rates. These implications are the opposite of those which in the 1950s were thought to prevail because of the mistaken presumption that the interest elasticity was increasing with the growth of money substitutes.

The important question for monetary policy is no longer seen as whether open market operations affect aggregate demand but as how the effect is distributed over time. In the standard theory, the smaller the effect on interest rates of an open-market operation, the smaller the initial effect on aggregate expenditures (the final effect at full-employment levels remains the same). Consequently, the earlier view implied that the growth of substitutes was lengthening the lag in monetary effects. But, insofar as a given monetary policy now has greater short-run effects on the economy but the same final effect, the average lag is shorter.

The growth of money substitutes may also affect the lag in monetary policy by reducing the ratio of money to total financial wealth or GNP, entirely aside from any effect via the interest sensitivity of money demand. A lower ratio of money to GNP means that the multiplier of the final effect of monetary policy on the economy is larger, and it is possible that a larger final effect takes longer to be reached following 
an initial change in the money stock. We mention this possibility as relevant to the lag question without being at all sure of the answer. Discussions of money substitutes in the literature have skirted the complex question of the dynamics of monetary policy. Yet a longer lag complicates the execution of monetary stabilization policies and is at the heart of the difficulties in pursuing a flexible policy.

In an earlier paper (Cagan and Schwartz 1975) we measured the lag between step turns in monetary growth and business cycle turns before and after World War II. We found that the lag appeared to be the same or slightly shorter in the recent period than formerly. So far, therefore, the growth of money substitutes has not made the lag perceptibly longer. Perhaps the effect on the lag of a decrease in interest sensitivity and a decline in the ratio of money to GNP have offset each other. Whether future reductions in money demand, if they occur, will henceforth work to lengthen the lag remains to be seen. In any event, even at present the lag is sufficiently long and unreliable, as experience in 1966, 1969, and 1970 demonstrates, to pose formidable problems for a flexible monetary policy.

One further implication of these results concerns the effect of fiscal deficits. According to the usual formulation, the effect of a government deficit on aggregate demand increases with the interest sensitivity of money demand. This dependence pertains to the residual effect after the deficit borrowing has produced adjustments in private portfolios and crowding-out effects on private investment that partially offset the initial impact on GNP of the change in the government budget.(Lags probably delay this offset.) An increase in the deficit financed by Treasury borrowing which, for example, raised the commercial paper rate by 1 percentage point would by one of our results reduce money demand by 0.7 percent compared with 2.7 percent in the 1920 s (table 8.2). The lower the interest sensitivity of money demand, the smaller is the effect on GNP of fiscal deficits.

Paradoxical as it seems at first, the growth of money substitutes has, if anything, increased the effectiveness of monetary policy and reduced the effect of fiscal policy.

\section{Appendix}

Data Sources

$M_{1}$ : Currency held by the public plus adjusted demand deposits at all commercial banks, quarterly averages of monthly figures, seasonally adjusted.

1921-31: Friedman and Schwartz (1970), table 1, col. 8. 
1954-71: ibid. through 1963; thereafter, Federal Reserve Bulletin, Nov. 1971, p. 884, and Mar. 1972, p. A-17.

P: 1921-31: Consumer price index $(1957-58=100)$. Bureau of Labor Statistics Release, Consumer Price Index-U.S.: All Items, 1913-60, Series A, quarterly averages of monthly figures.

1954-71: GNP deflator $(1958=100)$, quarterly, seasonally adjusted. The National Income and Product Accounts of the United States, 1929-65, through 1963; thereafter, Survey of Current Business, July 1968 for 196465 ; July 1969 for $1965-66$; July 1970 for $1966-67$; July 1971 for $1967-68$; July 1972 for 1968-71.

GNP: Gross national product in current prices, quarterly, seasonally adjusted at annual rates.

1921 -31: Compiled by Harold Barger and Lawrence R. Klein. See Business Cycle Indicators, vol. 2, G. H. Moore, ed., Princeton: Princeton Univ. Press for NBER, 1961, p. 133. Series 16.1 for series in form of quarterly totals.

1954-71: Same as for GNP deflator, above.

$i^{c}$ : $\quad$ Commercial paper rate, quarterly averages of monthly figures, seasonally adjusted by NBER.

1921-31: F. R. Macaulay, The Movements of Interest Rates, Bond Yields, and Stock Prices in the United States since 1856, New York: NBER, 1938, table 10, pp. A158-160.

1954-71: Weekly figures from Bank and Quotation Record of Commercial and Financial Chronicle; or

Call money rate, quarterly averages of monthly figures, seasonally adjusted by NBER through June 1931 .

1921-31: Same as for commercial paper rate, above.

Treasury bill rate, market yield on 3-month bills, quarterly averages of monthly figures.

1954-71: Supplement to Banking and Monetary Statistics, Section 12, Board of Governors of the Federal Reserve System, 1966, for 1954-63, pp. 51-52; thereafter, Federal Reserve Bulletin, monthly issues.

$i^{s}$ : $\quad$ Savings deposit rate, annual average of rates paid on U.S. postal savings and time and savings deposits of commercial banks, mutual savings banks, and savings and loan associations (omitted for 1921-31), each weighted by relative amounts outstanding, interpolated along a straight line to mid-quarter values.

1921-31: Friedman and Schwartz (1970), table 9, p. 173, extended to 1932; rate paid on member commercial bank time deposits, extrapolated before 1927 on basis of 
rate on mutual savings deposits, used as proxy for all commercial bank time deposits.

1954-71: same as for 1921-31, p. 174, extended to 1972.

\section{Notes}

1. Smith (1956), "I am arguing that the liquidity preferences of the public are typically quite elastic, so that it is ordinarily possible for potential spenders or their financial agents . . . to find buyers of such securities among the holders of idle cash balances without producing a rise in interest rates large enough to have a very great effect on expenditures"' (n. 45).

2. For a claim of empirical support for the liquidity trap, see Latané (1960). "If bonds are a good substitute for money, and other assets are relatively poor substitutes, which seems a reasonable hypothesis, then a change in money supply will tend to affect the bond market rather than spending on other assets. Under these conditions the interest elasticity of demand for cash balances has considerable influence on the effectiveness of monetary policy . . . Large differences in the logarithms of $M / Y$ are accompanied by very small differences in the logarithms of interest rates, thus indicating a very high interest elasticity of demand for proportionate cash balances if the observations fall on the same demand schedule. This would support the Keynesian 'liquidity trap' theory" (p. 448). See also Tobin (1947).

3. It is worth remembering that Keynes became disillusioned with monetary policy for the opposite reason, namely, that when needed, central banks failed to conduct bold operations in long-term debt markets.

4. $M_{1}$ is currency outside banks and adjusted demand deposits. $M_{3}$ includes also postal savings with the U.S. Post Office, time and savings deposits in mutual savings banks, commercial banks, and savings and loan associations. See Friedman and Schwartz (1970), table 1, cols. 8 and 13.

5 . The interest rate is measured in the regressions as a decimal, such as .04 . Then $b=(d \ln M) / d i=(d 100 \ln M) / d 100 i)$, the form given in the tables, may be referred to as the percentage change in demand with respect to arithmetic changes in the interest rate in percentage points.

6. Thus a coefficient of 1 means that a 1 percentage point increase in the interest rate (say from 4 to 5 percent per year) raises money demand by 1 percent. To convert to an elasticity, we may express this arithmetic change in the interest rate as a ratio or percentage change, 1/4 or 25 percent, and take the ratio of such changes in the two variables: $(d M / M) /(d i / i)=1 \% / 25 \%=.04$. Hence the coefficient can be converted to an elasticity by multiplying by the average level of the interest rate in decimal form. The average level of the commercial paper rate in the three periods in decimal form is .044 for $1921-$ $31, .035$ for $1954-65$, and .044 for 1954-71. As a further example applicable to all three periods, a coefficient of 5 approximates an elasticity of $5 \times$ $.04=.2$.

The very small size of our estimates generally agrees with the results obtained by Teigen (1964) and Laidler (1966), both of whom also used the commercial paper rate. Meltzer's estimates (1963) are much larger (by 5 to 25 times or so), which can be explained by his use of Durand's series on basic corporate bond yields. That series has appreciably less fluctuation than the paper rate and, in 
consequence, tends to give a larger regression coefficient. We obtain results comparable to Meltzer's for the savings deposit rate.

Most authors have measured interest rates in logarithmic form. In particular, Goldfeld (1973) obtained good results from such a form for the postwar period, and we present a comparable equation below in table 8.7. Otherwise, we used the nonlogarithmic form of interest rates because we believe it is more appropriate.

7. Juster and Wachtel (1972) argue that inflation creates uncertainty, which is the reason for the high ratios of household saving to disposable income in the late 1960s.

8. See Rasche (1972) and Cagan (1969).

9. If we constrain the GNP elasticity to unity but do not add another variable, the estimated interest coefficient for the later truncated period is higher (In $V=9.9 i^{c}+k$, compared with 1.4 for the earlier period), but this simply reflects an incorporation into the interest-rate coefficient of the unexplained upward trend in velocity.

10. Except mainly for the increase to 6 percent in 1968 for large negotiable certificates of deposit of 3-6 month maturity, and to $61 / 4$ percent for longer maturities, and in 1970 for savings deposits of twoyear maturity.

11. For the problem of deposits held by foreigners, which apparently became relatively large during this period and may have contributed to the change in trend of measured velocity, see Burger and Balbach (1972).

Since writing this passage in 1972 , we notice that velocity has been growing more rapidly again in 1973 and 1974. This may indicate that the slowing of the upward trend was confined to the period 1966-72 and reflected, perhaps, uncertainty over inflation (see n. 7) to which the public is now beginning to adjust.

Goldfeld (1973) fits a demand function to the full period 1952-1972 with reasonable success but by using a form of the equation which we find questionable. His results are discussed below.

12. Although the coefficient of 50 for the 1920 s is implausibly high, we do not argue that it should necessarily be lower then than later. A wholesale shift of money balances held as a store of wealth to other more attractive assets in the early post-World War II years may have reduced the elasticity of the remaining money balances with respect to these assets. This possibility, suggested by Marty (1961) and Teigen (1964), is discussed later.

13. The regression is $\ln V=k_{1}+k_{2}+f^{s}+b_{1} i_{1}+b_{2} i \xi$, where the subscript 1 denotes the earlier period 1921-31 and 2 the later period 1954-65, and the variables are zero outside their designated periods. The estimated coefficients are $f=18.4, b_{1}=1.5$, and $b_{2}=0.2$. Hence $b_{1}-b_{2}=1.3$ (with a $t$ statistic of 1.1).

14. The bottom panel regressions are in the form used by Goldfeld (1973) and differ from his only in that he used the time deposit rate instead of the average rate on time and savings deposits and he covered the longer period 1952.II-1972.IV. Goldfeld's equation (table 18, for ordinary least squares) gave:

\begin{tabular}{lllll}
\hline In GNP/P & $\begin{array}{l}\text { In Time } \\
\text { Deposit Rate }\end{array}$ & $\begin{array}{l}\text { In Commercial } \\
\text { Paper Rate }\end{array}$ & $\begin{array}{l}\text { Lagged } \\
\ln M / P\end{array}$ & $R^{2}$ \\
\hline .18 & -.04 & -.02 & .75 & .99 \\
$(5.4)$ & $(4.1)$ & $(8.2)$ & $(13.6)$ & \\
\hline
\end{tabular}


15. In this model the money-demand equation also includes the savings deposit rate and the change in the discount rate.

16. The Durbin-Watson statistics for the adjustment equations in tables 58 are somewhat higher than those for the previous regressions but are still well below 2 , indicating appreciable autocorrelation of the residuals. This is a deficiency of these equations which we did not believe would be properly handled by the standard assumption of a first-order linear relation between the residuals. Goldfeld does make the correction for first-order serial correlation of the residuals but also shows the results without the correction. There is virtually no difference in the regression coefficient of the commercial paper rate between his corrected and uncorrected equations (Goldfeld, 1973, table 18).

17. For some recent estimates, which fall at the lower end of the range, see Zwick (1971), Feldstein and Eckstein (1970), and Goldfeld (1973).

18. Barro and Santomero present estimates of this marginal rate based on survey data. When their estimate is subtracted from the savings deposit rate, the net rate reaches a peak in 1963 and remains practically level for the next five years. This plateau helps partially but does not by itself fully explain the slowing of the upward trend in velocity after 1966, since the breaks in trend of the two series differ in timing by several years.

19. The marginal rate compiled by Barro and Santomero (1972) is an annual series based on their survey of selected large banks. No independent data exist to indicate how representative it is of the entire banking system. Consequently, we have not used their series to derive a net interest rate.

Benjamin Klein (1973) measures the nonpecuniary yield of services on demand deposits by the open-market interest rate times the complement of the reserve ratio for demand deposits. The rationale is that this approximates the gross return to banks of their demand deposit liabilities, and under competition banks would use a fraction of it to attract deposits. This measure cannot be properly used in our short-run money equations for technical reasons, however, because the complement of the reserve ratio changes little in the short run. Hence this measure correlates almost perfectly with the open-market interest rate and provides no additional explanation of short-run variations in money balances.

20. Data on the ownership of demand deposits (Shapiro 1943; Federal Reserve Bulletin, various issues) show very little change between consumer and business sectors from 1929 to 1960 . But the reduction in interest-sensitive holdings within each sector could have been substantial. Unfortunately, we have no method of measuring such holdings and must rely on our estimates of the interest sensitivity of aggregate money balances.

Nevertheless, balances held by both sectors remain high in relation to sales or income in terms of any reasonable transactions use (see Friedman and Schwartz 1970, p. 107). "Nontransactions" holdings of money have by no means disappeared.

21. This inference assumes that the short-run demand for money is always equal to actual balances held, so that any change in balances held must be accompanied by sufficiently large changes in interest rates immediately to equate the demand and supply. The adjustment equations reported above allow for a lag in response of money demand to changes in interest rates but not for the obverse lag of portfolio adjustments in response to open market operations. But undoubtedly there is such an obverse lag, and it is relevant here to the extent that it is not the same in the earlier and later periods, as the text statement assumes. 
The disregard of this lag can lead to overstatement of the speed of monetary effects. Thus, if short-run money demand is always equal to the balance held, a lag in response of money demand to changes in interest rates, which as said implies large changes in interest rates as a result of portfolio adjustments to open market operations, can offset long lags in the response of investment expenditures to changes in interest rates and thus shorten the lag in effect on GNP (Tucker 1966). But such an offset does not necessarily occur if lags in portfolio adjustments mean as noted that short-run money demand is not immediately equated to the actual balances held. 